Immunobiol., vol. 184, pp. 402-409 (1992)

Rapid Communication

Institute of Virology and Immunobiology, University of Würzburg, Würzburg, Germany

\title{
Mechanism of MHC Class I Downregulation in HIV Infected Cells
}

\author{
Thomas Kerkau, Siegfried Gernert, Christian Kneitz, and \\ ANNEliese SCHIMPL
}

Received December 23, $1991 \cdot$ Accepted December 30, 1991

\begin{abstract}
HIV infection of $\mathrm{CD}^{+}$peripheral blood lymphocytes leads to a loss of MHC class I molecules on the surface of the infected cells as detectable by monoclonal antibody staining and flow cytometry. Incubation of the infected cells at $26^{\circ} \mathrm{C}$ or treatment at $37^{\circ} \mathrm{C}$ with peptides leads to upregulation of $\mathrm{MHC}$ class I to levels equal to those found on uninfected cells cultured under the same conditions. The data suggest that, after HIV infection, the mechanisms responsible for peptide generation, peptide transport and thus stable association between peptides and MHC class I molecules are severely affected.
\end{abstract}

\section{Introduction}

Following virus infection a variety of host defense mechanisms are being mobilized by the organism, including the activation of $\mathrm{CD} 8^{+}$cytolytic $\mathrm{T}$ lymphocytes which eventually help to eliminate virus infected cells. These $\mathrm{CD}^{+} \mathrm{T}$ cells recognize antigenic fragments in the context of major histocompatibility class I (MHC class I) molecules which bind and transport peptides derived from intracellularly degraded proteins to the cell surface, where the class $\mathrm{I} /$ peptide complexes are recognized by the $\mathrm{T}$ cells (1-6). A failure to express such complexes on the surface of infected cells would thus be expected to severely compromise the host and favor virus spread. To escape the hosts' defensive mechanisms, several viruses have developed strategies that lead to downregulation of MHC class I expression on the surface of the cells in which they replicate (reviewed in 7). Thus, adenovirus 12 inhibits class I production at the transcriptional level, while other viruses either bind $\beta 2$ microglobulin or the heavy chain of class I and thus prevent their export, together with viral peptides, to the cell surface. We and others $(8,9)$ have previously shown that HIV infection of peripheral blood lymphocytes or susceptible cell lines also leads to a reduction of class I expression on the surface of those cells heavily infected. Since we found that the amounts of class I specific mRNA were similar in 
infected and uninfected cells, it seemed likely that class I downregulation was due to posttranscriptional or posttranslational mechanisms. The present study was undertaken to more closely analyze the basis for the escape mechanism from the immune system operative in HIV infection.

\section{Material and Methods}

\section{Cell culture and HIV infection}

From buffy coat cells of HIV negative donors $\mathrm{CD}^{+}$cells were removed by a magnet after complexing them to Dynabeads (Dianova, Hamburg, Germany) coupled with a monoclonal antibody to human CD8. The resulting $\mathrm{CD}^{-}$cells were cultured in RPMI/10\% FCS at a cell concentration of $1 \times 10^{6} / \mathrm{ml}$ for 2 days with phytohemagglutinin (PHA-P; Difco, Detroit, MI, USA, $2 \mu \mathrm{g} / \mathrm{ml}$ ) in the presence of human rIL-2 $(40 \mathrm{U} / \mathrm{ml}$, a kind gift of Prof. SEBALD, Würzburg). Half of the cells were then infected with an MOI of 0.1 of HIV-1 (HTLV III B), the other half remained uninfected as a control.

\section{Upregulation of MHC class I at low temperature or by peptides}

Aliquots of the infected or uninfected cells were placed in a $26^{\circ} \mathrm{C}$ water bath for the last $6 \mathrm{~h}$ of a 4 day culture period, after which time all cells were processed for surface fluorescence staining. Alternatively, $5 \times 10^{5}$ cell aliquots of the infected cultures were exposed for the last $5 \mathrm{~h}$ of a 4 day culture period at $37^{\circ} \mathrm{C}$ to HIV gag peptide p 17-8 or p17-3 (Cambridge Research Biochemicals, England) at a concentration of $1 \times 10^{-4} \mathrm{M}$ in a total volume of $1.4 \mathrm{ml}$.

\section{Immunofluorescence staining and FACS analysis}

On day 4 after infection, aliquots from controls and infected cultures - cultured at $37^{\circ} \mathrm{C} /$ $26^{\circ} \mathrm{C}$ or treated with peptides as described above - were incubated with the following antibodies for $30 \mathrm{~min}$ on ice: $\mathrm{mAb}$ W6/32 (Serotec, Indianapolis, IN, USA), antihuman 32 microglobulin polyclonal antibody (DAKO, Hamburg, Germany), anti HLA A2 mAb and anti HLA Bw6 mAb (Biotest, Dreieich, Germany). The cells were washed twice in PBS and then incubated with $0.1 \mathrm{ml}$ fluorescein isothiocyanate (FITC)-conjugated goat anti-mouse immunoglobulin (Dianova, Hamburg) or FITC-conjugated swine anti-rabbit-immunoglobulin (DAKOPATTS, Denmark) for $30 \mathrm{~min}$ on ice, washed twice in PBS, fixed in $3.5 \%$ formaldehyde and analyzed on a FACScan (Becton Dickinson, Heidelberg, Germany).

\section{Results and Discussion}

During our investigations of the mechanisms responsible for the downregulation of $\mathrm{MHC}$ class I molecules in $\mathrm{HIV}-1$ infected $\mathrm{CD}^{+}{ }^{+} \mathrm{T}$-cells, we were puzzled by the observation that the extent of downregulation varied between individual blood donors and, occasionally, was more pronounced for $\beta 2$ microglobulin than for the heavy chain of class I (Fig. 1). In view of the comparable amounts of class I heavy chain specific mRNA in infected and uninfected cells (8) and the recent finding that $\beta 2-$ microglobulin loss from «empty» MHC class I molecules may precede loss of total class I complexes from the surface (10) we suspected that a posttranslational mechanism, possibly affecting the stability of class $\mathrm{I} / \beta 2$ complexes, was 
operative. The phenomenon was thus reminiscent of the reduced MHC class I expression recently described for the mutant mouse cell line RMA-S $(11,12)$ which appears to have a defect in the transport of peptide to the MHC class I molecules resulting in drastically reduced class I surface expression. The empty class I molecules thus formed are unstable at $37^{\circ} \mathrm{C}$ and those molecules still exported to the surface rapidly lose $\beta 2$-microglobulin. At reduced temperature $\left(26^{\circ} \mathrm{C}\right)$ the complexes can be stabilized. They can also be stabilized by peptides binding to the class I molecule in question, or by $\beta 2$ microglobulin at body temperature $(5,6,10,13-15)$.

To see whether an instability of MHC class I might also be responsible for the loss of surface MHC class I in HIV-infected cells, we infected PBL's of an HIV negative donor with HIV in vitro. At day 4 after infection we observed in a proportion of cells previously shown to be those that are heavily infected (8), a downregulation on the cell surface of, in this case,

\section{anti beta 2}

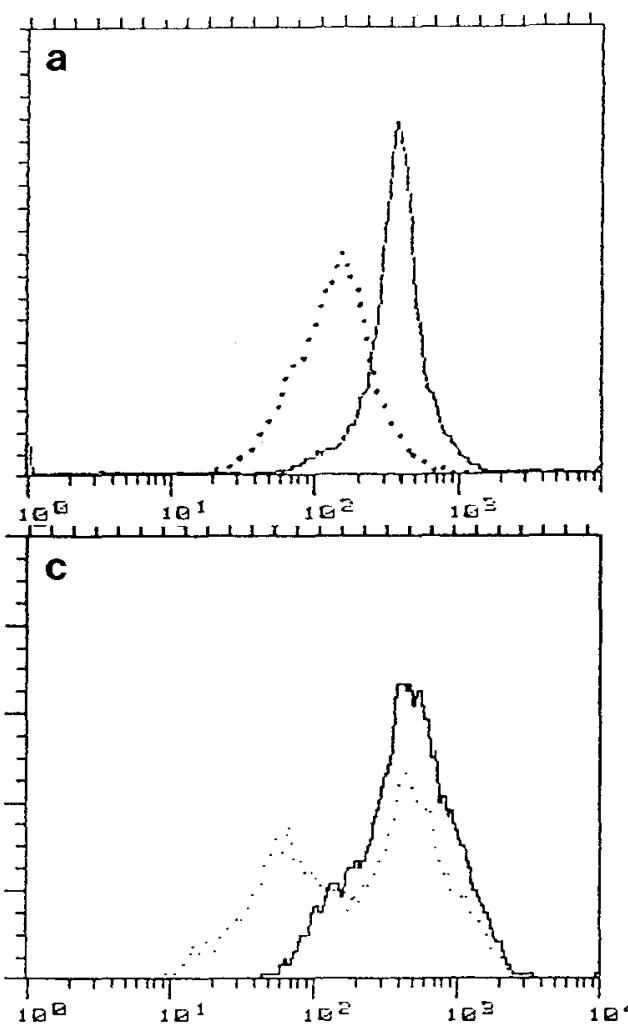

anti $\mathrm{Cl}$ 1-heavy chain

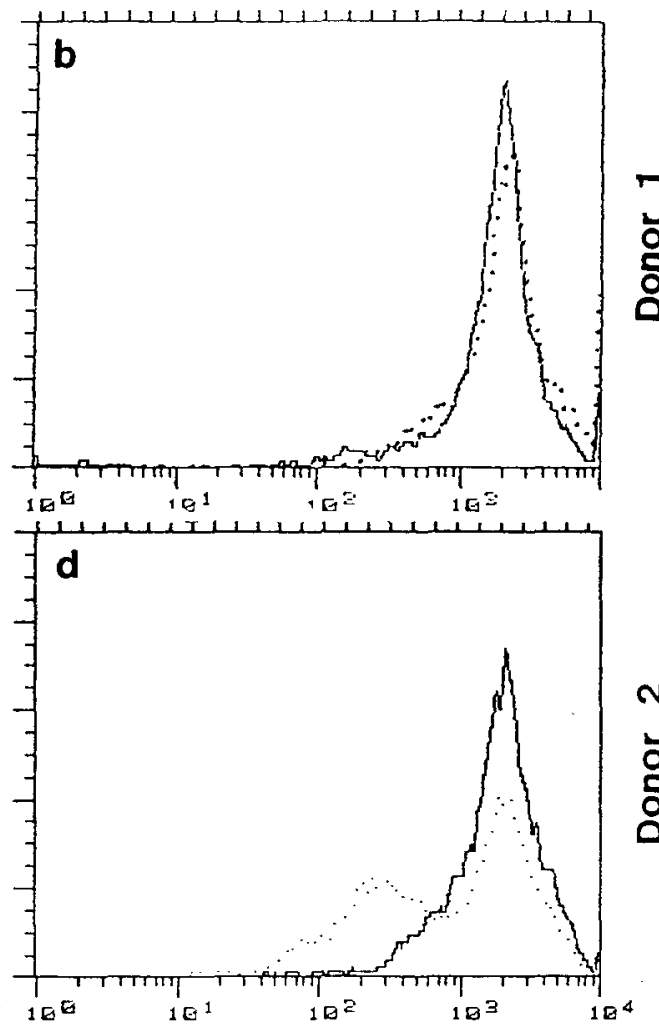

Figure 1. Indirect immunofluorescence staining of uninfected $(-)$ and HIV-infected $(\cdots \cdots)$ PBL's of two different blood donors with anti-human $\beta 2$-microglobulin $(\mathrm{a}+\mathrm{c})$ or with monoclonal antibody $W 6 / 32$ directed against class 1 heavy chain $(b+d)$. 


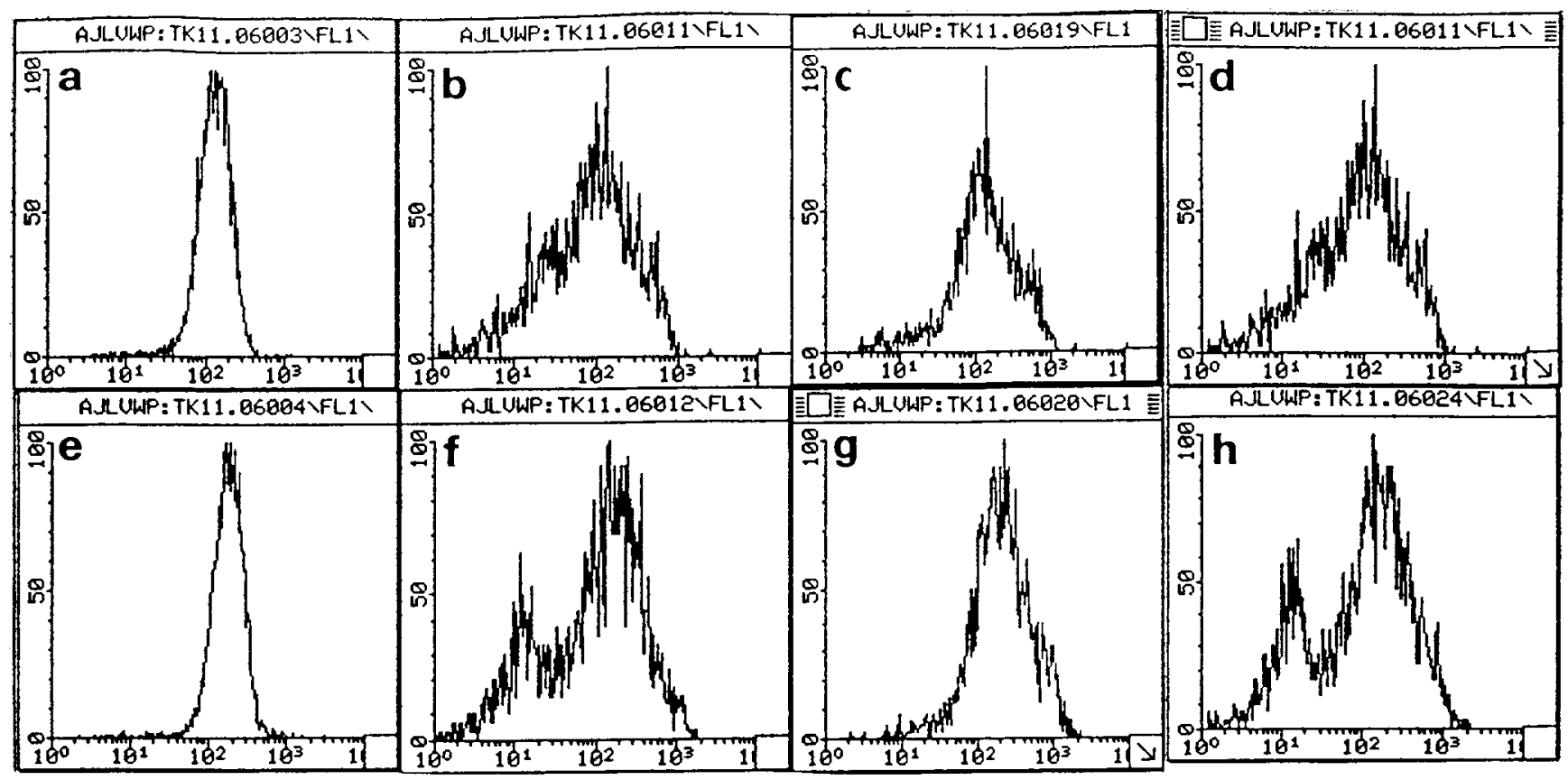

Figure 3. Expression of HLA A2 (a-d) or HLA Bw6 (e-h) on HIV-infected PBL's after exposure to various peptides for the last $5 \mathrm{~h}$ of a 4 day culture period. a+e, uninfected control culture; $b+f$, PBL's infected with HIV-1 for 4 days; $c+g$, PBL's infected with HIV-1 for 4 days and exposed to peptide p 17-8 for $5 \mathrm{~h}$; d+h, PBL's infected with HIV-1 for 4 days and exposed to peptide p 17-3 for $5 \mathrm{~h}$. 
anti-A2 and anti-Bw6 mAb in a proportion of cells. Exposure of the infected cells to exogenous A2 binding peptide p17-8 (16) for $5 \mathrm{~h}$ clearly increased the expression of HLA A2 (Fig. 3c) whereas the B8 binding peptide p17-3 (16) failed to do so (Fig. $3 \mathrm{~d}$ ). The peptide p 17-8 was also shown to upregulate class I molecules reacting with the anti-Bw6 antibody (Fig. 3g) while p17-3 (Fig. 3h) did not. Unfortunately we do not have any information on the HLA-B binding properties of these two peptides. However, it has been shown that peptide binding may occasionally be promiscuous (16-18).

Our data indicate that HIV-infected cells behave very similarly to RMA$S$ cells with respect to reversion of class I surface expression, suggesting a defect in peptide generation/transport or loading of class $I$ in the virus infected cells. Peptides derived from cytosolic proteins assemble with MHC class I molecules in the endoplasmatic reticulum or pre Golgi compartment $(5,19)$. In the absence of recognizable $N$-terminal signal sequences, such cytosolic peptides must be translocated across the membranes of the endoplasmatic reticulum by a novel mechanism. Recently, several investigators described the cloning-and-sequencing of «novel» genes encoded within the $\mathrm{MHC}$ which are candidates for peptide transporters (20-23) and may supply nascent class I MHC molecules with peptides, thereby fuelling the endogenous pathway of antigen presentation. Since downregulation of MHC class I molecules in HIV-1 infected cells can be overcome either by culture at reduced temperature or by the exposure to extracellular peptides we suggest the following hypothesis: In HIV-1 infected cells peptide generation and/or the peptide transporters may be «switched off» - possibly by HIV-1 derived gene products. As a consequence of this, MHC class I molecules would remain empty. Such empty class I molecules would either not associate with $\beta 2$-microglobulin and not be transported further to the cell surface or, if so, be unstable at body temperature. Differences in the stabilities of different MHC Class I allelic products, as recently suggested for B27 (24) might account for the variations in class I downregulation observed between different blood donors. Also, loss of $\beta 2$ has been shown to affect the conformation of the heavy chains still residing in the membrane (10). Conformational stability after $\beta 2$ loss may vary from allele to allele and thus render detection by the monoclonal antibody used more or less efficient.

A number of observations previously reported for AIDS patients could be explained on the basis of our findings. Thus, the increase in circulating $\beta 2$-microglobulin in sera of patients infected with HIV (25) might may be due to $\beta 2$-microglobulin chains having dissociated from peptide-less, unstable MHC complexes. This would eventually lead to the progressive decrease of MHC class I-positive lymphocytes and a defective expression of class I molecules recently reported for AIDS patients (26). Since peptide loading would not be possible in infected cells, the data could also explain why the $\mathrm{CD}^{+}$cytotoxic $\mathrm{T}$ cells detectable in vitro on target cells either incubated with peptides or infected with recombinant vaccinia virus 
expressing individual HIV proteins (27-30) do not seem to be very efficient in containing or terminating the disease in vivo. The unusally high frequency of $\mathrm{CD}^{+}$, Class II restricted cytolytic $\mathrm{T}$ cells observed in HIV positive donors might reflect an attempt of the host to compensate for the loss of an efficient class I restricted cytolytic response.

\section{Acknowledgments}

We thank Ursula Sauer for technical assistance and Eberhard Wecker and Thomas HüNIG for many stimulating discussions. This work was funded by the grant BGA II.031-87 of the Bundesgesundheitsministerium and the Fonds der Chemischen Industrie.

\section{References}

1. Bjorkman, P. J., M. A. Saper, B. Samraoui, W. S. BennetT, J. L. Strominger, and D. C. WILEY. 1987. The foreign antigen binding site and $T$ cell recognition regions of class I histocompatibility antigens. Nature 329: 513.

2. Townsend, A. R. M., J. Rothbard, F. M. Gotch, G. Bahadur, D. Wratth, and A. J. MCMichael. 1986. The epitopes of influenza nucleoprotein recognized by cytotoxic $\mathrm{T}$ lymphocytes can be defined with short synthetic peptides. Cell 44: 959.

3. Braciale, T. J., L. A. Morrison, M. T. Sweetser, J. Sambrook, M. Gething, and V. L. Braciale. 1987. Antigen presenting pathways to class I and class II MHC-restricted T lymphocytes. Immunol. Rev. 98: 95.

4. Krangel, M. S., H. T. Orr, and J. L. Strominger. 1979. Assembly and maturation of HLA-A and HLA-B antigens in vivo. Cell 18: 979.

5. Townsend, A., C. Öhlen, J. Bastin, H.-G. Ljunggren, L. Foster, and K. Kärre. 1989. Association of class I major histocompatibility heavy and light chains induced by viral peptides. Nature 340: 443 .

6. Ljunggren, H.-G., N. J. Stam, C. Öhlen, J. J. Neefjes, P. Höglund, M.-T. Heemels, J. Bastin, T. N. M. Schumacher, A. Townsend, K. Kärre, and H. L. Ploegh. 1990. Empty MHC class I molecules come out in the cold. Nature 346: 476.

7. Maudsley, D. J. and J. D. Pound. 1991. Modulation of MHC antigen expression by viruses and oncogenes. Immunol. Today 12: 429.

8. Kerkau, T., R. SchmitT-Landgraf, A. Schimpl, and E. Wecker. 1989. Downregulation of HLA Class I Antigens in HIV-1-Infected Cells. AIDS Res. and Human Retroviruses 5: 613 .

9. Scheppler, J. A., J. K. A. Nicholson, D. C. Swan, A. Ahmed-Ansari, and J. S. McDougal. 1989. Down-modulation of MHC-I in a CD $4^{+}$cell line, CEM-E5, after HIV1 infection. J. Immunol. 143: 2858.

10. Ortiz-Navarrette, V. and G. Hämmerling. 1991. Surface appearance and instability of empty H-2 class I molecules under physiological conditions. Proc. Natl. Acad. Sci. USA 88: 3594 .

11. LJUNGGren, H.-G. and K. KärRe. 1985. Host resistance directed selectively against H-2deficient lymphoma variants. J. Exp. Med. 162: 1745.

12. Kärre, K., H.-G. Ljunggren, G. Piontek, and R. Kiessling. 1986. Selective rejection of H-2-deficient lymphoma variants suggests alternative immune defence strategy. Nature 319: 675 .

13. Schumacher, T. N. M., M.-T. Heemels, J. J. Neefjes, W. M. Kast, C. J. M. Melief, and H. L. Ploegh. 1990. Direct binding of peptide to empty MHC class I molecules on intact cells and in vitro. Cell 62: 563.

14. Townsend, A., T. Elliott, V. Cerundolo, L. Foster, B. Barber, and A. Tse. 1990. Assembly of MHC class I molecules analysed in vitro. Cell 62: 285. 
15. Aosai, V., C. Öhlen, H. G. Ljunggren, P. Höglund, L. Franksson, H. Ploegh, A. TOWNSEND, KÄRRE, and H. J. STRAuss. 1991. Different types of allospecific CTL clones identified by their ability to recognize peptide loading-defective target cells. Eur. J. Immunol. 21: 2767.

16. Fkelinger, J. A., F. M. Gotch, H. Zweerink, E. Wain, and A. J. McMichael. 1990. Evidence of widespread binding of HLA class I molecules to peptides. J. Exp. Med. 172: 827.

17. Bouillot, M., J. Choppin, F. Cornille, F. Martinon, T. Papo, E. Gomard, M.-C. Fournie-Zaluski, and J.-P. Levy. 1989. Physical association between MHC class I molecules and immunogenic peptides. Nature 339: 473.

18. Chen, B. P., J. Rothbard, and P. Parham. 1990. Apparent lack of MHC restriction in binding of class I HLA molecules to solid-phase peptides. J. Exp. Med. 172: 931.

19. Hsu, V. W., L. C. Yuan, J. G. Nuchtern, J. LippincotT-SChwartz, G. J. Hämmerling, and R. D. KlausNer. 1991. A recycling pathway between the endoplasmatic reticulum and the Golgi apparatus for retention of unassembled MHC class I molecules. Nature 352: 441 .

20. Monaco, J. J., S. Cho, and M. Attaya. 1990. Transport protein genes in the murine MHC: Possible implications for antigen processing. Science 250: 1723.

21. Deverson, E. V., I. R. Gow, W. J. Coadwell, J. J. Monaco, G. W. Butcher, and J. C. HOWARD. 1990. MHC class II region encoding proteins related to the multidrug resistance family of transmembrane transporters. Nature 348: 738.

22. Trowsdale, J., I. Hanson, I. Mockridge, S. Beck, A. Townsend, and A. Kelly. 1990. Sequences encoded in the class II region of the MHC related to the «ABC» superfamily of transporters. Nature 348: 741.

23. Spies, T., M. Bresnahan, S. Bahram, D. Arnold, G. Blanck, E. Mellins, D. Pious, and R. DeMars. 1990. A gene in the human major histocompatibility complex class II region controlling the class I antigen presenting pathway. Nature 348: 744.

24. Benjamin, R. J., J. A. Madrigal, and P. Parham. 1991. Peptide binding to empty HLAB27 molecules of viable human cells. Nature 351: 74.

25. Zolla-Pazner, S., D. William, W. El-Sadr, M. Marmor, and R. Stahl. 1984. Quantitation of $\beta 2$-microglobulin and other immune characteristics in a prospective study of men at risk for acquired immune deficiency syndrome. J. Amer. med. Ass. 251: 2951.

26. Puppo, F., S. Brenci, R. Ruzzenenti, O. Bosco, L. Lanza, M. Scudeletti, M. Setti, and F. INDIVERI. 1991. Analysis of MHC class I molecules on peripheral blood lymphocytes of HIV-positive subjects. Int. Conference on AIDS, Florence, 1991. Abstract W.A. 1161.

27. Nixon, D. F., A. R. M. Townsend, J. G. Elvin, C. R. Rizza, J. Gallwey, and A. J. MCMiCHAEL. 1988. HIV-1 gag-specific cytotoxic T lymphocytes defined with recombinant vaccinia virus and synthetic peptides. Nature 336: 484.

28. Gotch, F. M., D. F. Nixon, A. J. McMichael, and L. K. Borysiewicz. 1990. High frequency of memory and effector gag specific cytotoxic T lymphocytes in HIV seropositive individuals. Intern. Immunol. 2: 707.

29. Walker, B. D., S. Chakrabarti, B. Moss, T. J. Paradis, T. Flynn, A. G. Durno, R. S. Blumberg, J. C. Kaplan, M. S. Hirsch, and R. T. Schooley. 1987. HIV-specific cytotoxic T lymphocytes in seropositive individuals. Nature 328: 345.

30. Plata, F., B. Autran, L. P. Martins, S. Wain-Hobson, M. Raphael, C. Mayaud, M. Denis, J.-M. Guillon, and P. Debre. 1987. AIDS virus-specific cytotoxic T lymphocytes in lung disorders. Nature 328: 348.

Dr. A. Schimpl, Institute of Virology and Immunobiology, University of Würzburg, 8700 Würzburg, Germany 